\title{
Éric Bordas, «Les Histoires du terroir, à propos des Légendes rustiques de George Sand»
}

\section{Brenda Piselli}

\section{Q OpenEdition}

1 Journals

\section{Edizione digitale}

URL: https://journals.openedition.org/studifrancesi/46115

DOI: 10.4000/studifrancesi.46115

ISSN: 2421-5856

\section{Editore}

Rosenberg \& Sellier

\section{Edizione cartacea}

Data di pubblicazione: 1 octobre 2007

Paginazione: 468

ISSN: 0039-2944

\section{Notizia bibliografica digitale}

Brenda Piselli, «Éric Bordas, «Les Histoires du terroir, à propos des Légendes rustiques de George Sand»», Studi Francesi [Online], 152 (LI | II) | 2007, online dal 30 novembre 2015, consultato il 24 novembre 2021. URL: http://journals.openedition.org/studifrancesi/46115 ; DOI: https://doi.org/ 10.4000/studifrancesi.46115

Questo documento è stato generato automaticamente il 24 novembre 2021.

\section{(c) 9 (i) $\Theta$}

Studi Francesi è distribuita con Licenza Creative Commons Attribuzione - Non commerciale - Non opere derivate 4.0 Internazionale. 


\title{
Éric Bordas, «Les Histoires du terroir, à propos des Légendes rustiques de George Sand»
}

\author{
Brenda Piselli
}

\section{NOTIZIA}

ÉRIC BORDAS, «Les Histoires du terroir, à propos des Légendes rustiques de George Sand», in «Revue d'histoire littéraire de la France», janvier 2006, n. 1, pp. 67-81.

1 Éric Bordas sottolinea che, attraverso le Légendes rustiques, la Sand si propose di dimostrare a uno stato centralizzatore la forza dei regionalismi, dotati di lingue e leggi proprie. L'autore considera quindi il problema relativo alla correttezza scientifica delle annotazioni linguistiche della Sand e i tre elementi che caratterizzano il linguaggio delle Légendes rustiques: l'attenzione al lessico regionale; la scarsa attendibilità sintattica, esempio della natura «poetica» e non filologica della scrittura sandiana; il plurilinguismo, poiché nell'opera si mescolano vocabolario del Berry, sintassi francese e prestiti normanni, piccardi, bretoni. Tuttavia, puntualizza Bordas, scopo della Sand fu quello di proporre una raccolta di racconti popolari, poiché ciò che le interessava non era la regione, ma «l'homme et son langage, sa parole» (p. 78). 